\title{
THE SELLER'S LIABILITY FOR MATERIAL DEFECTS OF THE GOODS AND THE BUYER'S LEGAL REMEDIES IN THAT CASE
}

\begin{abstract}
When the seller, in the sales contracts, delivers the goods with material deficiencies than the buyer will be entitled to use certain legal remedies against him. No legal system today questions this right of the buyer, but neither are the same legal remedies available to him everywhere, nor are the conditions under which they can be used the same. Substantial differences on this issue are noted between continental laws and common laws, but even the legal systems belonging to the same group do not have identical rules about them. That, to a significant extent, may be explained by the fact that the development path of the seller's responsibility for material defects in comparative law was not the same and for that reason an overview of that issue is given at the beginning of this paper. This is followed by the author's analysis of the buyer's notification on the defects of the goods as a condition for the seller's liability for material defects, and then the differences between systems of legal remedies of the buyer in continental and common laws are given, as well as solutions in several characteristic national laws within each group of laws. Rules of the Vienna Convention on contracts for the international sale of goods are exposed as a separate issue, keeping in mind their importance which is, above all, reflected in their impact on changes in national legislation in this area of law. In the conclusion it is noted that these changes flow toward the harmonization of the laws of the sale of goods, which facilitates trade and promotes economic prosperity.

Key words: contract of sale of goods, goods with material defects, notice of the buyer, responsibility of the seller, legal remedies
\end{abstract}

\section{Introduction}

From the seller's obligation to deliver the goods ${ }^{1}$ to the buyer arises his duty to guarantee that they have no material defects. In most continental laws this obligation of the seller is separated from the obligation to deliver, while in common laws it is considered that the seller guarantees to the buyer for the certain

Katarina Jovičić, PhD, Research Associate, Institute of Comparative Law, Belgrade, e-mail: katarinajovicic.rs@gmail.com

1 Only commercial contract for the sale of goods is considered in this paper, and not a consumer sales contract, which is a separate issue and, as such, is the subject to a special regulation. 
properties of the subject of contract by express and implied guarantees. ${ }^{2}$ When it turns out that the seller has delivered the goods with material deficiencies, then the buyer will be entitled to use certain legal remedies against him and nowadays there is no legal system that questions that right.

A comparative overview of the legal systems in relation to the regulation of legal remedies of the buyer in this situation shows that they differ, because not all remedies are permitted everywhere, nor are the conditions under which they can be used the same. Moreover, the differences in this area, especially between continental laws on one hand, and the common laws, on the other, are more important than for breach of any other obligation under the contract of sale of goods. This is, without any doubt, greatly affected by the fact that the development path of the institution of the seller's liability for defects is not the same in these jurisdictions.

\section{An overview of the development of the seller's liability for material defects}

The seller's liability for material defects in the civil law systems is based on the Roman law tradition. It has been developing gradually since the seller did not answer for a long time if, subsequently, after the contract was realized it turned out that the sold thing was defective. This is due to the then applicable rule "caveat emptor" - the buyer must be careful, which transfers the entire risk of defects onto the buyer. This view corresponded to an early structure of the sale, which was done in cash and in which the actions of contract concluding, handing over and payment took place at the same time. Under these circumstances the buyer was expected to examine the object of sale before the contract was concluded and as the contracts were, by the rule, related to the individual things, the buyer who would later find its defects could not ask the seller to give him the other thing of that kind. He also could not refuse to take the object of sale after the contract was concluded, because if he did so then he would be in default. Since the delivery of the thing with material defects is not considered as non-performance of the contract, ${ }^{3}$ in this situation the seller could only be

2 The obligation to guarantee the quality of the goods, according to the prevailing understanding in the comparative law, derives directly from the seller's obligations to deliver goods. This theory is particularly developed in the French legal doctrine, under which "guarantees arise from the seller's obligation to obtain the goods for the buyer and, when such an obligation is contracted, it is with the intention of the parties to be done in order to cause beneficial use." Robert Pothier-Joseph, Traité de la vente, T. III, Paris 1847, quoted in Krulj Vrleta: Dejstva ugovora o kupoprodaji - svojina, predaja, rizik, cena, Beograd 1972, 117.

3 It was held in the Roman law that when a debtor fails to fulfill the contract it can only be because he delayed the execution or because the execution has become impossible in the meantime. In other words, delay and impossibility of performance have long been the only 
responsible for a fraud according to the rules of tort liability, or for the breach of formal guarantees taken by a solemn promise he had made during the conclusion and execution of the contract. ${ }^{4}$

The weakening of the formalism of the Roman law has also weakened those guarantees of the seller and it's seemed more and more evident that there was the need to specifically regulate the issue of his liability for material defects. This problem in the Roman law was first solved by the "aediles curules" - the magistrates who were responsible to ensure order in the markets, which was increasingly disturbed by quarrels between buyers and sellers due to defects that have subsequently appeared on sold things (hidden defects). ${ }^{5}$ They issued two edicts where the buyers were granted the right to two suits: "actio redhibitoria" and "actio quanti minoris". In the first suit a buyer could claim from the seller to refund the price, provided that he returns the object of sale, while the second suit gives him the right to claim a price reduction if he decides to keep the thing despite its defects. Thus the Roman law established the responsibility of the seller for handing over things with material defects and his liability did not depend on whether he gave the explicit contractual promise that the object of sale was without defects or not.

In common law systems the seller's responsibility for material defects gradually developed too, initially in a similar way as in the Roman law. This is particularly confirmed by the development path of the institution of express warranty in the English law, according to which the seller is responsible only for the quality of thing sold which was expressly guaranteed by the contract. Over time, this view began to fit the needs of sales less and the reasonable buyer's demand for better protection in case the seller hands over the thing with material deficiencies. For that purpose the seller's liability was extended to the implied warranty for certain properties of the thing, ${ }^{6}$ for which the obligation arises under the law and implies a duty for the seller to submit things eligible for regular use. ${ }^{7}$

known forms of breach of contracts. Since the responsibility of the seller for handing over the defective goods could not fit in these forms, it was not even sanctioned as a breach of contract. See: Zimmermann Reinhard: The Law of Obligations: Roman Foundations of the Civilian Tradition, Cape Town, Wetton, Johannesburg 1990 and 1996, 783-800.

$4 \quad$ Ibid, 305. and further.

5 Clashes between buyers and sellers were especially present on the occasion of the slave trade and the wild beasts trade, since in these sales it often happened that later they turn out to be ill and because of that had a lower value for the buyer than those at which they were purchased. Since the buyers were not adequately protected in this situation they clashed with the sellers regarding this issue, which was disruptive to the markets and which has weakened the confidence in sellers and adversely affected the trade. Ibid, 317-318.

6 About the historical development of the seller's liability for latent defects in English law, see: Brown Ian, Commercial Law, London 2001, 447-448; Zimmermann, 306-307.

7 This issue is regulated by Sale of Goods Act from in 1979, for example: Art. 13. (implied terms that goods correspond with description, Art. 14. (implied terms about quality or fitness), etc.

Vol. 11, No 2, 2014: 37-54 
Common laws today, however, have not moved away much from this view and still assume the tacit will of the seller and the buyer about the guarantees for the properties of the sold goods, which is assumed whenever the terms of the contract have not provided otherwise.

\section{Objection to deficiencies as a condition of the seller's liability for material defects}

In order to obtain and maintain the right to legal remedies when the seller delivers the goods with material deficiencies, the buyer must notify the seller of the defects, in a timely and orderly manner. The buyer's notification is a condition for the seller's responsibility in this situation, and if it is not submitted, then the seller is not bound to act according to the buyer's requirements. ${ }^{8}$

In order to have a legal effect, the notification must be given within the time limit. ${ }^{9}$ In most laws, upon receipt of the goods the buyer should immediately examine the goods and object to the visible defects, while for the latent defects the commencement and duration of the period for objection are not defined in the same way in all laws. ${ }^{10}$ Thus, in the German law, it must be given immediately and without unnecessary delay from the date when the deficiencies were discovered, ${ }^{11}$ and a similar solution is provided in the Austrian and in the Swiss law. ${ }^{12}$ The Serbian law in commercial sales also provides that the buyer must object imme-

$8 \quad$ The German, Austrian and Swiss laws explicitly stipulate this obligation of the buyer ( $\$ 377$ of the German HGB, $\$ \$ 377,378$ of the Austrian HGB, Art. 201. of the Swiss Code of Obligations), although in the German and Austrian laws it is limited to commercial sales. In the Serbian law, the buyer's use of legal remedies is conditioned with the fact that the seller is timely and properly notified about the defects (Art. 488(1) of the Law of Obligations), as stipulated in Art. 39. of the Vienna Convention. In the American law the buyer is also obliged to notify the seller about the lack of conformity of the goods in order to obtain the remedies (Art. 2-607:3(a) Uniform Commercial Code-UCC), whereas in the English law the complaint is necessary only when the buyer intends to withdraw from the contract (Art. 35(1) Sale of Goods Act).

9 The provisions governing the issue of the time limit for a complaint submission are, by the rule, of dispositive nature so, in the contract, the parties can stipulate their longer or shorter duration.

10 However, the buyer does not lose the right to the legal remedy even when there is failure to object if the seller acted contrary to the principle of good faith (e.g. maliciously concealed the flaws, prevented the buyer from inspecting the goods or to timely submit a complaint, etc). See Art. 485. of Serbian Law of Obligations, Art. 44. of Norwegian Sale of Goods Act, Art. 483(3) of the Civil Code of the Russian Federation, Art. 40. of the Vienna Convention. Some laws resolve this situation so as to allow the buyer to give notice to the seller even after the expiry of the deadline, for example, Art. 203. of the Swiss Code of Obligations, $\$ 375(5)$ of the German HGB, Art. 33. of the Swedish Sale of Goods Act, and so on.

$11 \$ 377$ HGB.

$12 \$ \$ 377,378 \mathrm{HGB}$; Art. 201. of the Code of Obligations. 
diately after the discovery of the deficiency, whereas for civil sales it has to be done within eight days. ${ }^{13}$ In the Italian and the Portuguese laws the deadline for the buyer's objections is also fixed at eight days from the date of discovering the defects. ${ }^{14}$ In the Anglo-Saxon laws, as well as the Dutch law, it is enough to object within a reasonable time after discovering the defect, ${ }^{15}$ which is also the solution of the Vienna Convention for the contracts for the international sale of goods, ${ }^{16}$ without any doubt, the most important international source of law for that contract. ${ }^{17}$ Convention, in addition, provides that a notice may be given by the deadline of two years from the date of delivery of the goods to the buyer ${ }^{18}$ and such objective deadline is provided in a large number of national laws, but not in the same duration. For example, in the German and the Russian laws it is determined to two years, ${ }^{19}$ in the Swiss law to a year, ${ }^{20}$ while the Serbian law provides a period of six months. ${ }^{21}$ In any case, these short periods are given in order to prevent the buyer from thwarting the evidence of the condition of the goods by delaying with a notification of non conformity. It is also needed in order to promptly inform the seller about the problems in the performance of the contract, so that he should be able, to plan his future activities, considering the circumstances.

Usually, legal systems do not provide for specific requirements regarding the content of the notification in which the buyer complains about the lack of conformity of the goods, but, by its nature, it necessarily includes enough information so that the seller can clearly understand that this is a complaint which triggers the

13 The Serbian law prescribes different deadlines for civil and commercial sales and in the first case a complaint has to be submitted within 8 days, while in the second case it must be given immediately (Art. 481(1) and 482(1), the Law of Obligations). Article 1495(1) of the Italian Civil Code; Art. 471. of the Portuguese Civil Code

15 Article 2-607:3(a) of the UCCode; Art. 35. of the Sale of Goods Act. The same solution is provided in the Dutch law (Art. 7:23.1. BW)

16 United Nations Convention on Contracts for the International Sale of Goods, adopted in Vienna, in 1980.

17 Article 39(1). A determination of reasonable time shall be given according to the circumstances of the case. It is not the same for the perishable goods and those which are not. Also, the term may depend on whether the buyer wants to keep the goods at a reduced price, or he intends on returning them to the seller and so on. See: Schwenzer Ingeborg: "Article 39”, 630-633, in: Schwenzer Ingeborg (ed.): Schlechtriem \& Schwenzer Commentary on the UN Convention on the International Sale of Goods (CISG), Oxford 2010.

18 Paragraph 2. of article 39. However, the buyer can complain even after the deadline if the seller was acting in bad faith and if there is a reasonable excuse for not sending a proper notice within a reasonable time (Art. 40. and 44).

$19 \$ 438$ BGB; Art. 477(2) of the Civil Code of the Russian Federation.

20 Article 210(2) of the Code of Obligations.

21 Article 482. of the Law of Obligations.

Vol. 11, No 2, 2014: 37-54 
right to a legal remedy, not just any other statement or claim. ${ }^{22}$ In this respect, the buyer should specify what kind of defect is questioned ${ }^{23}$ and give enough information to the seller, proving that the goods are his and not someone else's. It is clear that the content of a specific notice, in practice, to a large extent depends on the nature of the goods, but it also depends on the buyer, his knowledge and ability. Thus, the precise objections are expected from an expert in the goods to which the contract relates, but also, it is expected from those who are not experts to indicate the deficiencies in sufficient detail because general complaints such as: "the goods are of poor quality", "the equipment must be repaired", "it is not what we expected", and so on, are too vague and not specific enough to be taken into account. $^{24}$

The buyer, by the rule, is not bound to state what legal remedies he intends to use, within the notice, and such a request would not be justified if we take into account that it has to be submitted in the short term and that the buyer does not have enough time to decide about that issue, too. ${ }^{25}$

In comparative law, as a rule, there are no specific requirements as to the form of notice for material defects, for a contrary view could burden the relations of the buyer and the seller, and thus complicate the exchange of goods. Therefore, this notice can be communicated verbally, through the appropriate documents, in electronic form, as well as in every other way, though, for the purpose of legal certainty, it is desirable to be in a form that is suitable to serve as evidence that the notification has been given.

\section{Legal remedies of the buyer when the seller delivers the goods with material deficiencies}

As it is already noted in the introduction, the legal systems do not provide the same sanctions for the seller who has delivered the goods with material deficiencies to the buyer. The following will expose principal differences between continental and common laws in relation to this issue and it will present, within

22 For example, if the buyer requests delivery of other goods then it does not mean that he is, at the same time, complaining about its deficiencies; it is necessary that the seller, based on the buyer's requirements, may conclude that the reason for the new order is a non-conforming delivery. See Kröll Stefan, "Article 39», 602-603, in: Stefan Kroll, Mistelis Loukas, Pilar Viscasillas P. (eds.): The UN Convention on the Contract for the International Sale of Goods (CISG), Munich and Oxford, 2011.

23 This obligation of the buyer does not mean that he is bound to state all and every deficiency or defect.

24 See Kröll Stefan, 602-607; Schwenzer Ingeborg, 624-627.

25 However, there are no obstacles to provide, within the contract, the buyer's obligation to do so when giving a notice or any time thereafter, as this issue is in the domain of the autonomous will of the contractual parties. 
each group, solutions characteristic for the national legal systems. In addition to this, special attention shall be paid to a system of sanctions provided in the UN Convention on Contracts for the International Sale of Goods (hereinafter Vienna Convention) ${ }^{26}$, which is important not only for its specific solutions, but also because of the impact in this sphere which performs on the changes in international and national sources of law.

\subsection{Continental laws}

Continental legal systems give the creditor the right to different legal remedies in the event that the debtor breaches the contract of the sale of goods. Most of them, according to the provided conditions, are available in any case where the debtor fails to perform the contract but, in addition, continental laws also provide for specific remedies that are related to specific violations of contract.

Thus, in the sales contract, a buyer can almost always claim the specific performance of the contract and/or compensation for damages or, when the conditions are met, for the contract to be avoided. However, if the seller has delivered the goods with material deficiencies to the buyer, in addition to the above remedies has the right to claim the price reduction. It is implied that he sets on that request when he decides to keep the things in spite of their shortcomings

Although the above-mentioned legal remedies are known in almost all continental laws, not all of them are available under the same conditions. Their differences, which manifest themselves primarily in respect of the termination of the contract due to material defects, are best illustrated by the examples of the French, Austrian and Swiss laws. This segment will showcase the solutions provided in the Serbian law too, not only because it belongs to the same group of laws, but because the rules are similar to those in the German law and, as such, sufficiently distinctive to be also specifically mentioned.

The French law: A system of remedies that the French law gives to the creditor in a case when the debtor has violated the contract ${ }^{27}$ is characterized by two specificities. First, it is a rule which provides that a termination of contract because of non-performance can be achieved solely on the basis of the court decision, not on the statement of the creditor or ex lege. ${ }^{28}$ Another specificity is reflected in the restriction of creditor's rights to demand a specific performance

$26 \quad$ Supra note 16.

27 The general rule of Art. 1184(2) CC provides that the creditor decides independently whether to require the fulfillment of the contract in kind, compensation of damages or the termination of contract.

28 Article 1184(3) CC. In the French law there is a notion present, that the parties to the synallagmatic contract are mutually bound and that each of them gives their consent to perform a contractual obligation, provided that the other party undertakes to carry out their own, so if one of them deviates it is considered then that the tacit condition for the termination of the contract has taken place. However, termination does not act ex lege, but only

Vol. 11, No 2, 2014: 37-54 
of the contract in a case when the debtor's contractual obligation is to do or not to do, which includes the buyer's demands when the seller delivers the goods with defects. This is explicitly provided in Art. 1142. of the Civil Code, which states: "Any obligation to do or not to do resolves itself into damages in a case of non-performance on the part of the debtor" ${ }^{29}$

The rule of judicial termination of the contract applies in cases where the seller has delivered the goods with defects too, but for the buyer in this situation there is a special legal remedie available - the right to redhibition. It allows him to request a price refund from the seller, on the condition that he returns the delivered goods. ${ }^{30}$

The rule of redhibition apparently derives from the Roman law and the buyer's suit actio redhibitoria. It is difficult to draw a clear distinction between that legal remedy on one hand, and the termination of the contract on the other, with regard to their equal effects: each party returns to the other what is received in the name of the execution of the contract. However, these claims can differ significantly in the way of implementation, since the termination of the contract can not be achieved without a court's decision, while it is not a requirement for redhibition. ${ }^{31}$ In this case, the buyer also is entitled to recover damages from the seller, the all damage if the seller knew of the defects of the thing, or reimbursing the cost of sale and restitution of the price if he was unaware of the deficiency. ${ }^{32}$

The buyer's legal remedies against the seller who has delivered the goods with material deficiencies are affected by the above cited rule in Art. 1142. of the Civil Code, given that the obligations to deliver and the related guarantees for the quality of the goods delivered are, as a rule, qualified as an obligation to

at the discretion of the court. See: Jelena Perovic, Bitna povreda ugovora - Medunaronda prodaja robe, Beograd 2004, 116-117.

29 The idea behind the limitation above is that the state should not be coercive of its citizens, who are free to decide how they will resolve the issue of non-performance of the contract, implicitly as long as it does not conflict with mandatory rules.

30 Article 1644. CC provides that the buyer has the right to return the thing and to claim the price refund, or to keep the thing and claim a refund of the part of the purchase price which is awarded by an expert. He does not have the right to seek replacement of goods and this rule obviously comes from the Roman law, which also did not know this sanction. A similar solution can be found in the Italian law (Art. 1492, CC). Redhibition had been known in the earlier German law $(\$ 462, \mathrm{BGB})$, but this was abolished with the reform of contract's law in 2002, and now the question of buyer >s remedies when the seller delivers the goods with material deficiencies is regulated by $\$ 437 \mathrm{BGB}$, which does not provide that right of the buyer.

31 If the seller refuses to voluntarily comply with the buyer's request for the redhibition, then there is no obstacle for the buyer to try to enforce it in the court proceedings. He may also claim from the court to terminate the contract, but to achieve this it is necessary for the anticipated conditions to be met, above all the deficiency being so serious that the judges gain confidence that the termination is appropriate in this case.

32 Articles 1645. and 1646. CC. 
do something. Limiting the right to enforce the specific performance of the contract in this case the French law favours indirect ways of its fulfillment in kind. Thus, for example, it encourages the buyer to hire a third party to remedy defects by repair in the seller's account, or to buy goods in replacement if the deficiency can not be eliminated by the means of repair ${ }^{33}$ rather than forcing the seller to perform the contract.

The buyer, in addition to the aforementioned law, may require from the seller to reduce the price if he decides to keep the goods despite the deficiencies. The French law is exceptional in relation to that buyer's request because, unlike most other laws, it provides that the price reduction rate is based on the expert's estimates. $^{34}$

The Austrian law: the Austrian law also does not give unlimited freedom to the buyer to terminate the contract if the seller delivers the goods with material deficiencies, but the way in which it regulates the matter makes it specific. The starting point is, in fact, the distinction between recoverable and unrecoverable defects and termination can only be realized in the first case. Under the term unrecoverable in the aforementioned context, those defects whose nature is such that they can no longer be removed are considered and that they interfere with the regular use of goods. ${ }^{35}$ When this is not the case, then the defect is considered recoverable and the buyer can choose between a claim for a price reduction and the enforced specific performance of the contract. In any case the buyer is entitled to a compensation for damages.

The Swiss law: In Switzerland, the buyer's right to choose legal remedies is limited, too. However, in contrast to the Austrian law, the limit criterion is not a qualification of the deficiency, it is a matter rather left to the final evaluation

33 However, the practice of the French courts shows that they, in spite of the provisions of Art. 1142, in most cases allow the enforcement of these obligations, while referring to the above restriction only when the performance of the contract is no longer possible due to the physical, legal, or moral reasons. See: John Bell, Boyron Sophie, Simon Whittaker: Principles of French Law, Oxford 1998, 348; Barry Nicholas: French Law of Contract, London 1982, 211.

34 In other laws, including the Vienna Convention, the amount of the reduced price is determined, as a rule, by the relative method in which the value of the goods supplied is divided by the value that it would have if there were no defects, so that the resulting amount is multiplied by the agreed price. See: Peter Huber, Alastair Mullis: The CISG: A New Textbook for Students and Practitioners, München 2007, 252; Müller-Chen, "Article 50", 774, in: Schwenzer Ingeborg (ed.); Will Michael, “Article 50”, in: Bianca C. Massimo (ed.), Bianca Bonell Commentary on the International Sales Law, Milan 198; Ivo Bach, "Article 50", 758-759, in: Kroll, S., Mistelis, L., Pilar P. V. (eds.); Anette Gärtner, Britain and the CISG: The Case for Ratification - A Comparative Analysis with Special Reference to German Law, The Hague 2000-2001, http://www.cisg.law.pace.edu/cisg/biblio/gartner.html \# IIA (16.04.2014); Jovičić Katarina: “Zahtev za sniženje cene kod ugovora o međunarodnoj prodaji robe”, Pravni život br. 11/2012, 360-362.

$35 \$ 932$ BGB provides that the buyer may terminate the contract in its entirety only when a defect is of such nature that it cannot be removed and that it bothers a regular use of the thing.

Vol. 11, No 2, 2014: 37-54 
of the court. In other words, when the buyer finds that the goods have hidden defects he can freely, without any restrictions, seek termination of the contract or, instead, claim a price reduction. These particular rights are explicitly provided in Art. 205. of the Code of Obligation, and which one of them will finally be realized is a subject to competent court's decision. ${ }^{36}$ In addition to these remedies the buyer may require a delivery of substitute goods only under the condition that the contract of sale relates to the replaceable items. ${ }^{37}$ Bearing in mind that contracts for the sale of goods are often concluded in relation to the replaceable goods, it is clear that the buyer, regularly, has a right to that legal remedy. In any case, the buyer is entitled to a compensation for the damages.

The Serbian law: The Serbian Law of Obligations ${ }^{38}$ also limits the buyer's right to avoid the contract if the seller delivers the goods with material deficiencies. This limitation is reflected, above all, as a rule that the buyer cannot terminate the contract immediately after he notes problems, but this right is acquired when the deficiencies are not corrected by the means of repair on the seller's, even in the additional period of time. ${ }^{39}$ The contract is then terminated ipso jure unless the buyer immediately declares that he remains in the contract and that he expects its performance. ${ }^{40}$ An additional period of time is not necessary to be given when the seller, after being notified of the deficiencies, communicates to the buyer that he will not fulfill the contract or, if the circumstances of the case clearly show that the seller will not be able to do so in a subsequent period ${ }^{41}$. Nearly identical rules on this issue can be found in the German law. ${ }^{42}$

36 Article 205(2) of the Code of Obligation says: "If an action for termination the contract has been initiated, the judge is free to judge the compensation for the reduction in value only provided that the circumstances do not justify a termination of the sale contract.

37 Article 206. of the Code of Obligation

38 The Serbian Law of Obligations, Official Gazzete SFRY, 29/78, 39/85, 45/89 i 57/89, Official Gazette FRY, 31/93 and Official Gazette SMN, 1/2003.

39 However, termination of the contract is not permitted for just any deficiency because the slight deficiency is not taken into account (Art. 478. par. 3). This rule is confirmed by Art. 492. of the Law of Obligations, which regulates the issue of termination of the contract due to partial defects predicting the contract is terminated only for the part of the goods that have defects, unless the buyer has a legitimate interest to receive the entire thing as a whole. Based on that, a general rule is drawn that the buyer will be entitled to terminate the contract due to material defects only when he cannot realize the benefits legitimately expected from the contract, due to which the purpose of the contract was brought into question.

40 This is due to the general rule of the procedure of termination of the contract in the Law of Obligations, under which the creditor acquires the right to terminate the contract only after the debtor fails to perform the contract even in the additional period of time (Art. 126). This general rule is confirmed by a special rule for the sale contract (Art. 490, paragraph 1. of the Law of Obligations).

41 Article 490. paragraph 2.

42 See: $\$ \$ 323,437$ BGB. 


\subsection{Common laws}

The system of legal remedies for breach of contract in common laws is simpler than in continental laws. The creditor, in fact, can always use a claim for damages, which is also his primary remedy for any breach of contract by the debtor. Termination of the contract is possible only if the breach is so serious that it questions the purpose of the contract. In addition to the damages and termination of the contract, the creditor has no right to use other remedies which are common in civil law, or they can be used in exceptional cases. Thus, the request for the specific perfomance of the contract allows the discretion of the court in special cases, while a claim for price reduction is not an independent legal remedy and only a claim for damages can be used in this function.

The seller's liability for material defects of the goods is regulated by those general rules too, but in addition to them there is also a special rule: the buyer's right to reject non-conforming goods. When using this right the buyer achieves the effect as if the contract was terminated, because the rejection of goods simultaneously entitles him to claim the price refund. ${ }^{43}$ Rejection of goods is known in the English, as well as the U.S. law, but the rules by which it is done in these laws are not identical.

The English law: Contractual obligations in the English law differ according to their importance and if they are of vital importance to the contract than they are called conditions, and if not, then they are called warranties. ${ }^{44}$ Only a violation of the conditions gives the right to the creditor to terminate the contract, while in a case of the violation of warranties he can use a claim for the compensation of damages. The quality of the goods that are the subject of the contract may also be considered as a condition or a warranty, depending primarily on what the parties have agreed. If they have failed to negotiate on the issue, then it is regulated according to the dispositive legal rules that provide for so-called implied guarantees (implied terms) on the characteristics of the goods. ${ }^{45}$ When

43 The English and American laws do not recognize direct termination due to material defects of the goods, but the right to reject the goods. In the English law it is only possible when the condition is violated and provided that ownership of the goods has not been transferred to the buyer, while in the U.S. law the buyer is allowed to reject the goods in the case of a higher degree of non-conformity with the contract.

44 A condition would be a statement or promise which is transformed into a contractual provision and which, if not met, allows the other party to terminate the contract. In contrast, a warranty does not have such, vital importance for the contract and its contempt does not call the purpose of the contract into question, and the creditor cannot terminate it on that basis. In some cases the law itself provides that the contract contains certain terms, socalled tacit guarantees, irrespective of whether the parties have agreed of them. See William Anson, Principles of the English Law of Contract, Twenty-first edt. Oxford 1959, 114-124.

45 In this case the seller is obliged to deliver the goods of appropriate quality because he is bound to do so by the Sale of Goods Act. With time, it came to the notion that certain conditions and warranties are tacit (implied), because the buyers and the sellers often fail

Vol. 11, No 2, 2014: 37-54 
the seller violates these contractual guarantees, express or implied, then the buyer can reject the goods if the deficiency represents a condition, ${ }^{46}$ while if the warranty is violatied than he is entitled only to a compensation claim. In this, second case, compensation plays a role of price reduction as the buyer retains the goods while paying less than it was specified in the contract.

The American law: In case of an improper delivery the American law also gives the buyer a choice between acceptance and rejection of the entire delivery, or part thereof if only a part of the goods is with defects. ${ }^{47}$ However, unlike the English law, the buyer's right to reject the goods is not limited by the seriousness of the defects, ${ }^{48}$ but he is free to do so because of any deficiencies. This rule is known as the "perfect tender rule", which was developed in the U.S. law at the end of the nineteenth century and, as such, is entered in Art. 2-601 of the American Uniform Commercial Code. According to it, the buyer is not required to prove that the deficiency is significant to the extent that the purpose of the contract is questions, it is sufficient to be established that there is a deficiency so that he could refuse to accept the delivery. However, if the buyer receives the goods and it subsequently turns out that the goods have hidden defects, or if the deficiencies were not remedied timely although the buyer has reasonably expected from the seller to do so, then he has the right to revoke a acceptance and request a price refund (which corresponds to the termination of the contract). But, the buyer may have this right only on condition if the defects of the goods are so serious that they question the purpose of the contract. ${ }^{49}$

\subsection{The Vienna Convention}

The Vienna Convention, while regulating the legal remedies of the buyer, provides a general rule that the buyer in any event of breach of the contract by the seller can: request a performance of the contract, claim damages, claim a reduction of the price or terminate the contract. ${ }^{50}$ The buyer may also use these legal remedies when the seller delivers the goods which do not conform with

to agree on them. Initially, these tacit guarantees appeared as trade customs, and later they were clearly and successfully codified in the Sale of goods Act (Art. 14). Ibid, 120.

46 Articles 35A and 36, Sale of Goods Act.

47 Article 2-601, UCC.

48 Contractual obligations in the American law are also graded by their importance, but not to the conditions and warranties, but the immaterial and material (fundamental) breach.

49 Article 2-608, Uniform Commercial Code: In these mentioned cases the buyer must revoke his acceptance within a reasonable time after he discovers od should have discovered the ground for it, and before any substantial change in condition of the goods which is not caused bu their own defects.

50 Article 45. A request for a price reduction is related to the case when the seller delivers the goods which do not conform with the contract. 
the contract ${ }^{51}$ and on that basis it is concluded that the Convention, in relation to this issue, follows the solutions from the continental laws. However, a more detailed analysis of this finding questions it, because it shows that its rules have a sufficient distinctiveness to be characterized as original ones.

If we start from the buyer's request for performance of the contract then, in accordance with Art. 46. of the Convention, it is expressed as a request to remedy the lack of conformity by repair, or as a request for the delivery of substitute goods. This is in accordance with the solutions for the same issues found in continental laws, but unlike them the Convention provides for the possibility to deviate from this rule. An exception is provided for in Art. 28, which allows the court to refuse the buyer's claim for a specific performance of the contract ..." if he would do so under its own law in respect of similar contracts of sale not governed by this Convention". This restriction has the greatest application before the courts of common law, where such requests of the buyers are only exceptionaly approved. This way the Convention makes a compromise between the rules of continental and common laws, which is needed to ensure its widest possible application. It is true, however, that the compromise is reached at the expense of the buyer because his right to this legal remedy is seriously questioned.

Rules of termination also represent a compromise since it can be achieved in two ways: first, when the violation of the contract is so severe that it can be qualified as a fundamental breach of contract, and second, when a debtor, even in additional time fixed by the creditor, does not perform the contract. Connecting the right to terminate the contract for the concept of fundamental breach of contract is close to common laws to the understanding of the contractual obligations graded according to their importance, in which only the most serious violations may lead to that effect. ${ }^{52}$ However, the concept of fundamental breach of contract is not identical to the division of the contractual terms on conditions and warranties in the English law, nor is it equal to the division between material and immaterial (fundamental) breach in the U.S. law. Qualifying a breach of contract as a fundamental breach of contract with the purpose to be the basis on which the contract can be terminated should follow the rules of Art. 25. of the Convention, ${ }^{53}$ which apply regardless of similar qualifications that are encountered in some national laws. The Convention, beside that, provides that the contract can be terminated when the debtor, even in the additional time given by the creditor, does not fulfill the contract. A similar rule is found in many continetnal laws but the buyer, under the Convention's rules, can do it only when the

51 The term of "non-conforming goods", according to Art. 35. of the Convention, also includes the case when the seller delivers the goods of inadequate quality.

52 The fundamental breach of contract is regulated in Art. 25, while the buyer's right to terminate the contract if the seller makes a fundamental breach of contract is regulated in the Art. 49.1(a).

53 See: Björkkund Andrea, “Article 25”, 333-351, in: Kröll, S., Mistelis, L., Pilar, P. V. (eds.); Schroeter Ulrich, “Article 25”, 398-437, in:Schwenzer Ingeborg (ed.).

Vol. 11, No 2, 2014: 37-54 
seller does not deliver the goods, not when it is delivered and it turns out that there are deficiencies. ${ }^{54}$ Accordingly, the buyer does not have the right to terminate the contract because of the material defects based on expiry of the additional period ot time, but it can be done only if the defect, as such, is qualified as a fundamental breach of contract. ${ }^{55}$

\section{Conclusion}

For a long time the seller's liability for defects has not been recognized as his contractual obligation whose violation gives the buyer the right to legal remedies. The development path of this institute was carried out differently in continental and common laws and the rules regulating the matter are different. This is most reflected in the fact that more legal remedies are available for the buyer in the continental than in common laws, where he can only claim damages from the seller and, exceptionally, terminate the contract.

This difference can be explained by the fundamentally different organization of private law in the two mentioned groups of legal systems. If we start from the continental law, within it the overall obligations are, in accordance with the tradition of the Roman law, governed by one law - the law of obligations. These laws depart from the source of obligation as the central thesis, so that the contracts, as a source of obligation, are one of the questions they regulate. In a section devoted to contracts the issue of their non-performance is particularly regulated, as a rule, by predicting the forms in which it occurs. In principle, the starting point is the understanding that only the conduct of the debtor which may be considered as a predicted form of non-performance of the contract can produce legal effects in the form of acquisition of the legal remedies on befalf of the creditor against the debtor. A case when the seller delivers the goods with deficiencies is one of those forms and it regularly gives the buyer rights to several legal remedies (the request for the performance of the contract, the request for the performance of the contract in an additional period of time, the request for a price reduction, the claim for damages and termination of the contract), which he uses at his choice, under the conditions foreseen.

\footnotetext{
54 Article 49, paragraph 1(b).

55 The solution of the Vienna Convention is followed in the UNIDROIT Principles of International Commercial Contracts (Art. 7.3.1.) as well as in the Principles of European Contract Law (Art. 9:301). The advantage of that attitude for the buyer is reflected in the fact that he can terminate the contract as soon as he notices the defect, provided that the defect is a fundamental breach of contract. In practice, however, situations where both the buyer and the seller agree on that issue are rare and if the seller objects to the buyer's request to terminate the contract on that basis, then it is practically impossible to do so until the competent court decide about it. Since the buyer has no other options to terminate the contract, the conclusion is that this solution is more favorable to the seller.
} 
As opposed to this, the laws of obligation are not usual in common laws and contracts are not governed as one of the sources of obligations, rather being considered as a separate category of private law (beside tort law, property law, family law and succession law). The sales contract is regularly governed by a special law which does not pay attention to the forms of non-performance of the contract, because they have no significance in these laws since they start from the understanding that any deviation from the contract represents non-performance. Instead, the central issue in the breach of contract is a question of legal remedies and finding the most effective solutions to problems resulting from it. It is recognized, through centuries of practice, that the compensation is adequate and effective protection of the creditor for almost all cases of breach of the sale of goods contracts, as well as for the buyer to whom the seller has delivered the goods with material deficiencies. Notwithstanding, if the defects are sufficiently severe and serious, then he can terminate the contract .

The approach taken on this issue which we find in the Vienna Convention is a compromise between these systems because, similar to common laws, it is based on the understanding that any violation of contract is a breach of contract, but the remedies to which the creditor in this situation is entitled are not limited to the request for compensation of damages and termination of the contract, but he may also use other legal remedies which are commonly available in continental laws. The fact that the Convention has, for several decades, been successfully implemented around the world confirms that this compromise, which takes the best from both legal systems, is successfully formulated. Based on the fact that its solutions are increasingly embedded in international and national sources of law for the contract of sale of goods, it can be expected that in the future this area of law will develop in this direction. It will minimize the differences between the legal systems and contribute to the simplification of the conditions under which the sale of goods takes place.

\section{Literature}

- Anson William (1959): Principles of the English Law of Contract, Oxford.

- Bach Ivo (2011): “Aricle. 50", 749-767, in: Kröll Stefan, Mistelis Loukas, Pilar P. Viscasillas (eds.), UN Convention on Contract for the International Sale of goods (CISG), München and Oxford.

- Barry Nicholas (1982): French Law of Contract, London.

- Bell John., Boyron Sophie, Whittaker Simon (1998): Principles of French Law, Oxford

- Björkkund Andrea (2011): „Article 25”, 333-351, in: Kröll Stefan, Mistelis Loukas, Pilar P. Viscasillas (eds.), UN Convention on Contract for the International Sale of goods (CISG), München and Oxford. 
- Brown Ian (2001): Commercial Law, London.

- Gärtner Anette (2000-2001): "Britain and the CISG: The Case for Ratification - A Comparative Analysis with Special Reference to German Law", The Hague, http://www.cisg.law.pace.edu/cisg/biblio/gartner.html\#iia (16.4.2014).

- Huber Peter, Mullis Alastair (2007): The CISG: A New Textbook for Students and Practitioners, München.

- Jovičić Katarina (2012): „Zahtev za sniženje cene kod ugovora o međunarodnoj prodaji robe“, Pravni život br. 11/2012, 353-368.

- Kröll Stefan (2011): „Article 39”, 594-626, in: Kröll Stefan, Mistelis Loukas, Pilar P. Viscasillas (eds.), UN Convention on Contract for the International Sale of goods (CISG), München and Oxford.

- Krulj Vrleta (1972): Dejstva ugovora o kupoprodaji - svojina, predaja, rizik, cena, Beograd.

- Müller-Chen (2010): Article 50, 770-780, in: Schwenzer Ingeborg (ed.): Schlechtriem \& Schwenzer Commentary on the UN Convention on the International Sale of Goods (CISG), Oxford.

- Perović Jelena (2004): Bitna povreda ugovora - Međunarodna prodaja robe, Beograd.

- Pothier Robert-Joseph (1847): Traité de la vente, T. III, Paris.

- Schroeter Ulrich (2010): “Article 25”, 398-437, in: Schwenzer Ingeborg (ed.): Schlechtriem \& Schwenzer Commentary on the UN Convention on the International Sale of Goods (CISG), Oxford.

- Schwenzer Ingeborg (2010): „Article 39”, 622-642, in: Schwenzer Ingeborg (ed.): Schlechtriem \& Schwenzer Commentary on the UN Convention on the International Sale of Goods (CISG), Oxford.

- Will Michael (1987): “Art. 50", 368-376, in: Bianca C. Massimo (ed.), Bianca-Bonell Commentary on the International Sales Law, Milan.

- Zimmermann Reinhard (1996): The Law of Obligations: Roman Foundations of the Civilian Tradition, Cape Town, Wetton, Johanesburg.

Paper received: May $15^{\text {th }}, 2014$

Approved for publication: May $19^{\text {th }}, 2014$
Rad primljen: 15. maj 2014. Odobren za štampu: 19. maj 2014. 


\section{Dr Katarina Jovičić, istraživač saradnik \\ Institut za uporedno pravo u Beogradu}

\section{ODGOVORNOST PRODAVCA ZA MATERIJALNE NEDOSTATKE ROBE I PRAVNA SREDSTVA KUPCA U TOM SLUČAJU}

\section{S a ž e $\mathbf{t}$ a $k$}

Kada prodavac kod ugovora o prodaji isporuči robu sa materijalnim nedostacima, tada kupac stiče pravo da protiv njega upotrebi određena pravna sredstva. Ovo kupčevo pravo ni jedan pravni sistem danas ne dovodi u pitanje, ali mu nisu ista pravna sredstva svuda dostupna, niti su isti uslovi pod kojima ih može koristiti. Suštinske razlike o ovom pitanju zapažaju se između kontinentalnih prava i prava common law, ali ni prava koja pripadaju istoj grupi o tome nemaju identična pravila. To se u značajnoj meri može objasniti okolnošću da razvojni put odgovornosti prodavca za materijalne nedostatke u uporednom pravu nije bio isti, zbog čega se na početku rada daje osvrt na to pitanje. Nakon toga sledi izlaganje o prigovoru kupca kao uslovu prodavčeve odgovornosti za materijalne nedostatke, a potom se daje prikaz razlika između sistema pravnih sredstava kupca u kontinentalnim pravima i pravima common law, kao i rešenja nekoliko, karakterističnih nacionalnih prava u okviru svake grupe. Pravila Bečke konvencije o ugovorima o međunarodnoj prodaji robe su izložena kao posebno pitanje s obzirom na njen značaj koji se, pre svega, ogleda u uticaju na promene nacionalnih propisa u ovoj oblasti prava. U zaključku se konstatuje da te promene teku u pravcu harmonizacije prava prodaje robe, što olakšava trgovinu i podstiče ekonomski prosperitet.

Ključne reči: ugovor o prodaji robe, roba sa materijalnim nedostacima, prigovor kupca, odgovornost prodavca, pravna sredstva 
